\title{
Contribution of Farm Products to Farmer's Livelihood and Household Consumption in Leyte, the Philippines
}

\author{
Carol A. Neal \\ School of Natural and Rural Systems Management, The University of \\ Queensland, Gatton 4343, Australia
}

\begin{abstract}
This paper describes the agroforestry farming systems through which crops, trees and small farm animals are produced and consumed by three farming families on Leyte Island, the Philippines, and the extent to which they contribute to the farmers' livelihoods and wellbeing. A survey using semi-structured personal interviews was carried out to obtain data on cost savings of farm-grown products consumed, health benefits derived and costs incurred in managing and maintaining each farm. There were notable differences in crop-tree arrangement and management methods used by the farmers. An estimate of the amount of product that was consumed by the households was conditional on crop choices and intensity of effort and inputs and offsets from off-farm income. Informal arrangements for bartering food, and coconut and bamboo product sharing for community use, made precise valuation of these products difficult, but comparative values against local market prices were placed on marketable produce. Labour and other inputs between the farms varied widely, depending on the type of product. In addition to crops grown as a source of income, portions of farm products were grown specifically for home consumption, and some non-consumable products were exchanged between households. The farmers had a basic understanding of the nutritional value and health benefits of all the food products they consumed for daily energy, health and medicinal purposes. They also believed that consuming their own farm-grown produce generated savings compared with quality and value of the same product from the local markets.
\end{abstract}

Keywords: agroforestry farming systems, food quality, livelihood, nutritional value, savings benefits

\section{INTRODUCTION}

Smallholders in developing countries often obtain a substantial amount of their food and other household inputs from their own land rather than market purchases. Little is known about the extent to which farm grown food products contribute to smallholder livelihoods in the Philippines. However, an important factor is how trees, non-tree crops and animals are integrated for biophysical and socio-economic sustainability. Cropping patterns are primarily determined by land type and market 
accessibility (distance from the nearest road) (Gomez and Gomez 1983). For this study, three farms in Leyte Province in the Philippines on which food crops are grown in conjunction with trees, were selected. Farming methods and crop patterns were identified, and the types of produce that were grown and consumed by the case study households were analysed to determine how these contributed to household livelihoods.

Mixed farming systems provide farmers with an opportunity to diversify risk relative to growing a single crop species, to use labour more efficiently, to have a source of cash for purchasing farm inputs, and to add value to crops and their byproducts (Devandra and Thomas 2002). Magcale-Macandog (2006) observed that the main motivations of farmers planting trees include cash income, raw materials for home and furniture construction, food and medicine.

Multi-storeyed intercropping where cash crops are planted in conjunction with coconuts and trees provides the young coconuts and trees with nutrients and weeding benefits while the farmers gain short-term returns from their annual crops (Nissen et al. 2001). Shading also seems to play a major role in determining the productivity of intercrops in the lower canopy (Gomez and Gomez 1983). Hence, farmers typically replace light-demanding crops with more shade tolerant annual species (Nissen et al. 2001) and perennials as shading increases with the development of the overstorey. The primary aim of intercropping with annuals is to support the farm family while the main crop is still unproductive, whereas perennial intercropping aims to increase landuse efficiency during the most productive years of the main crop (Gomez and Gomez 1983).

Wages of hired labour make up the largest single item of expenditure on most farms (Upton 1996). Organised barter systems and exchange of agricultural products and seeds among neighbours and relatives are also common (Frei and Becker 2004). Most farming families in developing countries have family members involved in offfarm work (Upton 1996), which represent an alternative form of employment and source of income and may influence farm management practices.

Rice, poy (white taro, Colocasis esculenta), ubi (blue taro/yam, Xanthosoma violaceum), camote (sweet potato, Ipomea batata), and kangkong (water spinach, Ipomea aquatica) are known by Filipino farmers to be sources of food energy. Other products, okra (Abelmoschus esculentua) and eggplant (Solanum melongena) are used as a natural means of abating common heart and kidney related diseases. Ampalaya (bitter melon, Momordica charantia) is well known and consumed by Filipinos for prevention and treatment of Type 2 diabetes mellitus (Lewis 1977), a disease of national significance in the Philippines.

\section{Rationale for This Study}

This study was undertaken as one of the activities of Australian Centre for International Agricultural Research (ACIAR) Project ASEM/2003/052 - Improving Financial Returns to Smallholder Tree Farmers in the Philippines. One component of 
this project has been to identify smallholder agroforestry farming systems from a whole-farm perspective. The study reported here falls within this component, and focuses on the extent to which farm products contribute to farmers' livelihood and household consumption. The objectives were to:

(i) describe the farming systems of the three case study farms, and household demographics in relation to how the farmers live from their farms;

(ii) identify and compare farm products and quantities used within and between households;

(iii) review farmers' level of awareness of the nutritional value of farmproduced food consumed by the household;

(iv) obtain farmers' opinions regarding benefits in terms of quality and savings in monetary terms by direct use of products from their farms.

\section{RESEARCH METHOD}

\section{Selection and Labelling of Case Study Farms}

The farming systems on three smallholder farms at barungays Anahawan, Cebuana and Mabagon in the south-west of Leyte Province were examined. The farm selection process was integrated with an existing ACIAR socio-economic database. Farms were selected which have similar size (in hectares), and similar geographical, topological and climatic conditions. The farms at Anahawan and Mabagon comprised four land parcels, and the farm at Cebuana comprised five. The farms were producing a diverse range of main crops that contributed to the household income, and other crops that produced some household income and were also used for home consumption.

For reporting findings of the study, each of the case study farms was named after the Barangay in which they were located, and the land parcels allocated a code, based on three letters of the name of the Barangay in which they were located. The codes used to identify the farms are Awn- for the Anahawan farm and Ceb- for Cebuana farm in the Municipality of Bato, and Mbn- for the Mabagon farm in the Municipality of Hindang. The individual parcels were subsequently allocated the names:

- Awn-house - multiple mixed crops nearest to the house,

- Awn-coco - main crop coconut (Cocus mucifera),

- Awn-mono - monocrop of sweet potato with coconut and gmelina (Gmelina arborea) as boundary markers,

- Awn-steep - very steep block with bamboo (Gigantochola atter), coconuts and some taro, mostly natural vegetation understorey,

- Ceb-house - mixed tree farm and rice paddy at house,

- Ceb-gully - fruit trees with vegetable patches on a slope with a gully forming part of the boundary, 
- Ceb-hwy - a few solitary papaya and banana plants bordering sweet potato with highway and creek marking other boundary lines,

- Ceb-fallow - gmelina trees and coconut upslope from grassed fallow,

- Ceb-tree - tree farm of scattered trees with grass groundcover,

- Mbn-tree - tree farm near house $1 \mathrm{~m}$ x $1 \mathrm{~m}$ spacing,

- Mbn-multi - multi level mixed crops with trees on steep contoured slope,

- Mbn-fallow - fallow rice field and some crops, and

- Mbn-new - young gmelina trees interplanted with young mango (Mangifera indica) trees and coconut, some crops downslope, some fallow.

The case study farms are located in the municipalities of Bato and Hindang in south-west Leyte. Variation in elevation and slope (Table 1) is typical of the karst tropical tower over cockpit geomorphologic land system of the region (Smithson et al. 2002).

Table 1: Topography and total farm area of the three case study farms

\begin{tabular}{|c|c|c|c|}
\hline Farm & $\begin{array}{c}\text { Elevation } \\
\text { (masl) }\end{array}$ & Slope (\%) & $\begin{array}{c}\text { Total farm } \\
\text { land area }(\mathrm{ha})\end{array}$ \\
\hline Anal & $63-115$ & $\begin{array}{l}15-20 \text { undulating to rolling, to } 35- \\
40 \text { moderately steep to very steep }\end{array}$ & 4.65 \\
\hline Cebuana & $15-20$ & $15-20$ to $30-35$ & 4.25 \\
\hline Mabagon & $10-130$ & Zero to greater than & 4.30 \\
\hline
\end{tabular}

Source: Topography information provided by the Hindang local government unit.

The farms consisted of four individual land parcels at Anahawan and Mabagon, and five land parcels at Cebuana. The land parcels range in area from 0.25 to 2.75 ha, and are located at distances up $2 \mathrm{~km}$ from the farmers' house. There is sealed road access to Awn-house, unsealed road to the Ceb-house parcel and the balance of the parcels are accessible by walking track only.

\section{Method of Data Collection from Case Study Farms}

Primary data were obtained by: (i) interviews with the farmers; (ii) respondent participation by way of completing weekly data sheets on the type and proportion of farm-grown produce they consumed each week; and (iii) direct observation. A qualitative survey was conducted using a semi-structured questionnaire, in the local dialect of Cebuano, and with responses translated directly onto the survey form in English. Discussions focussed on estimating costs incurred by the farmers by way of the type of labour used and chemical inputs (fertilizers, pesticides and treatments for animals), farmers' knowledge of nutritional value of the crops they consumed, and 
opinions regarding benefits and cost savings through consumption of farm-grown products.

With the exception of domestic household chores, fieldwork tasks are not usually separated between family members, and therefore the head male and head female of each household were interviewed together. Details of land parcels were recorded by direct observation, with hand-drawn maps and photographs of features of relevance to assist in describing the farming systems. Sections of each parcel were photographed sequentially with a digital camera and connected in a computer generated Panorama maker to form panoramic pictures of each land parcel. A Filipino enumerator conducted the interviews and identified plant species. Spatial arrangement on farms were documented.

A simple data recording form for listing the farm-grown products that were consumed by each of the households during each of four weeks was distributed to the three households. The form included a series of scale bars against each product type. The farmers were requested to place a cross on each scale bar to indicate the proportion of farm-grown products they consumed during each week of the study. Each farm was re-visited for four consecutive weeks to collect the completed forms and discuss their contents. The volume or weight of the produce consumed by each household was not quantified, because only one of the three farmers possessed a set of scales.

\section{RESULTS}

\section{Crop-tree Arrangement}

Rice and ampalaya (a climbing vine grown on bamboo trellises) were the main crops planted as monocultures at the Anahawan and Cebuana farms (Tables 2 and 3), and coconuts were planted along boundary lines, scattered, or widely spaced in an informal grid pattern greater than $2 \mathrm{~m} \times 2 \mathrm{~m}$ at Anahawan. Spacing distances are indefinable because as each coconut plant is removed an additional seedling is planted at an available gap within the grid pattern. Bananas at the Cebuana farm (Table 3) were planted along the boundary, in no fixed pattern. Perimeter planting was used across the three farms to define property boundaries. Other crops, particularly vegetables and fruit trees, were mixed or planted in no fixed pattern, although some vegetable crops that were grown for sale at the local markets were grown in single species blocks at Anahawan.

Gmelina trees and coconuts were planted mostly along boundaries at Ana-house, coconut and monoculture areas (Table 2). Ceb-house contained gmelina, mahogany (Swietenia macrophylla) and coconuts on a wide spacing of a greater than $2 \mathrm{~m} \times 2 \mathrm{~m}$ grid pattern to mark the property boundary (Table 3). Anahawan had a total of 100 gmelina and 21 mahogany trees, and on Cebuana a total of 100 gmelina and 40 mahogany trees were planted in small blocks. 
Table 2. Plant species and arrangement within land parcels at Anahawan

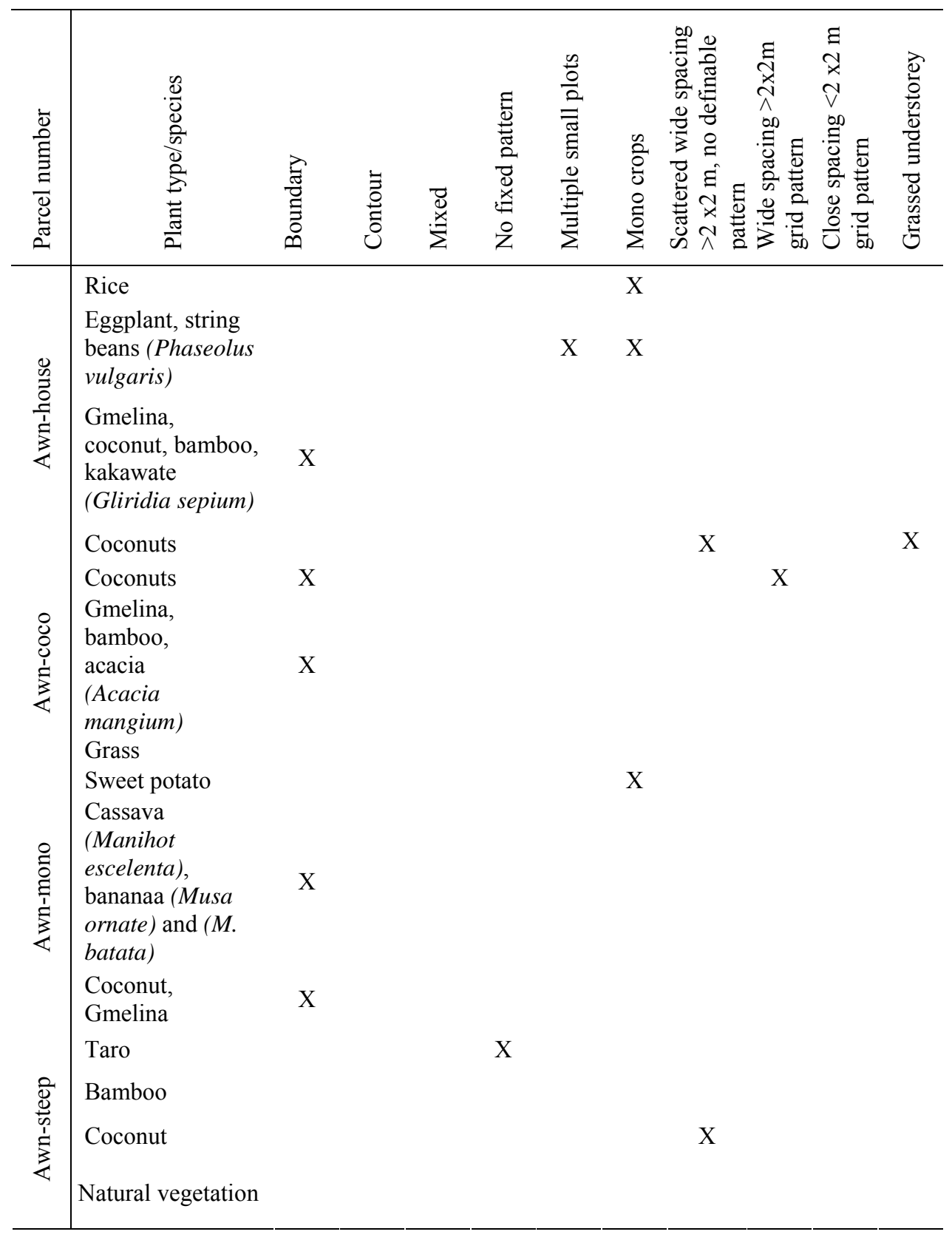


Table 2. (Cont.) Plant species and arrangement within land parcels at Anahawan

\begin{tabular}{|c|c|c|c|c|c|c|c|c|c|c|}
\hline 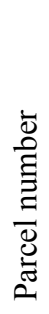 & 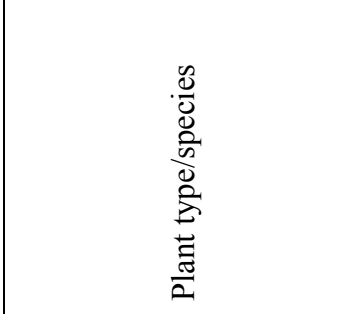 & 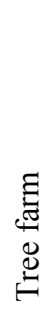 & 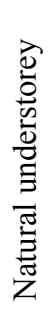 & 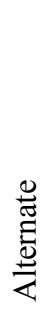 & 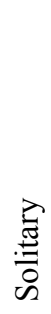 & $\begin{array}{l}\frac{z}{\sigma} \\
\frac{0}{\pi} \\
\text { I }\end{array}$ & $\sum_{2}^{\infty}$ & 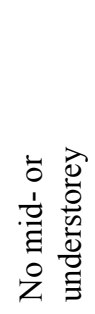 & 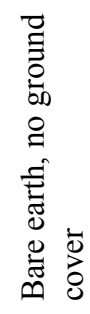 & 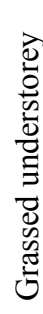 \\
\hline \multirow{4}{*}{ 章 } & Rice & & & & & & \multirow{4}{*}{$\mathrm{X}$} & & & \\
\hline & $\begin{array}{l}\text { Eggplant, string beans } \\
\text { (Phaseolus vulgaris) }\end{array}$ & & & & & & & & & \\
\hline & $\begin{array}{l}\text { Gmelina, coconut, } \\
\text { bamboo, kakawate } \\
\text { (Gliridia sepium) }\end{array}$ & & & & & & & & & \\
\hline & Coconuts & & & & & & & & & $\mathrm{X}$ \\
\hline \multirow{3}{*}{\begin{tabular}{l}
0 \\
8 \\
0 \\
1 \\
1 \\
3 \\
\multirow{2}{1}{}
\end{tabular}} & Coconuts & & & & \multirow{3}{*}{$\mathrm{X}$} & & & & & \\
\hline & $\begin{array}{l}\text { Gmelina, bamboo, } \\
\text { mangium }\end{array}$ & & & & & & & & & \\
\hline & Grass & & & & & $\mathrm{X}$ & & & & \\
\hline \multirow{3}{*}{ 总 } & Sweet potato & & & \multirow[b]{3}{*}{$\mathrm{X}$} & & & & & & \\
\hline & $\begin{array}{l}\text { Cassava (Manihot } \\
\text { escelenta), banana (Musa } \\
\text { ornate and M. batata) }\end{array}$ & & & & & & & & & \\
\hline & Coconut, gmelina & & & & & & & & & \\
\hline \multirow{4}{*}{ 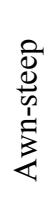 } & Taro & & & & \multirow{4}{*}{$\mathrm{X}$} & & & & & \\
\hline & Bamboo & & & & & & & & & \\
\hline & Coconut & & & & & & & & & \\
\hline & Natural vegetation & & $\mathrm{X}$ & & & & & & & \\
\hline
\end{tabular}

Of the four land parcels at the Mabagon farm, the most diverse crop-tree planting arrangement was on 2 ha at Mbn-multi (Table 4). Here, the farming system was a mixed multiple-level contour planting on a steep slope with a combination of timber and fruit trees and young coconuts along contour lines. Vegetables and other crops grown between contour rows or as understorey crops along the contour lines consisted mostly of coffee (Coffee arabica), cassava, karlang (red taro) (Colocasia rubra), poy 
(white taro), cacao (cocoa) (Theobroma cacao), and ubi (blue taro/yam). An area of about 0.25 ha was left uncultivated. There were a few seven-year-old gmelina and four-year-old mahogany trees. The farmer was not concerned about competitive effects of the maturing trees on the understorey crops. He believed that mahogany was slow growing, and as the trees grew larger, he would continue to grow shade-tolerant crop species such as taro. There was no harvest plan and the trees were to remain in the ground for income when needed and for his children's inheritance. The Mbn-tree trees growing adjacent to the house contained about 200 gmelina, 100 mahogany and 200 ipil ipil, planted in a $1 \mathrm{~m} \times 1 \mathrm{~m}$ grid pattern. The earth was swept bare, with all available leaf litter and twigs used to fuel household fires for cooking and smoking away mosquitoes. 
Table 3. Plant species and arrangement within land parcels at Cebuana

\begin{tabular}{|c|c|c|c|c|c|c|c|c|c|}
\hline 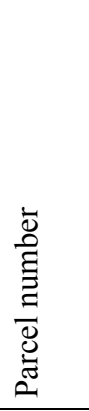 & 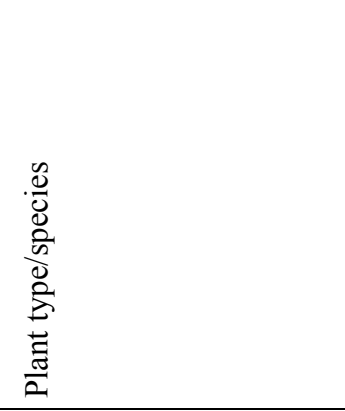 & 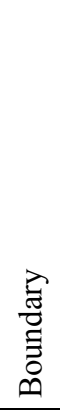 & 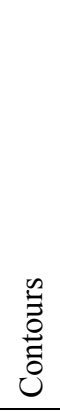 & $\begin{array}{l}\vec{U} \\
\stackrel{x}{\Sigma}\end{array}$ & 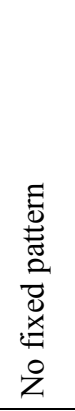 & 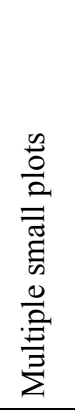 & 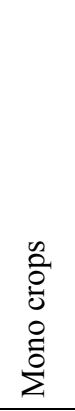 & 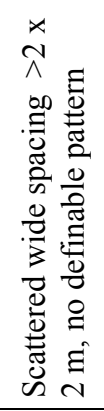 & 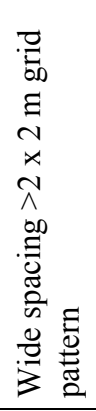 \\
\hline $\begin{array}{l}0 \\
0 \\
\frac{0}{0} \\
\frac{1}{1} \\
00 \\
0\end{array}$ & $\begin{array}{l}\text { Rice } \\
\text { Mahogany } \\
\text { Gmelina, mahogany, } \\
\text { coconuts } \\
\text { Siqwa (snake gourd) } \\
\text { (Trichosanthes } \\
\text { anquina) }\end{array}$ & $X$ & & $X$ & $\mathrm{X}$ & & $\mathrm{X}$ & & $X$ \\
\hline 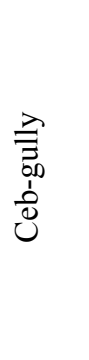 & $\begin{array}{l}\text { Vegetables } \\
\text { Ampalaya } \\
\text { Papaya, Mango } \\
\text { Ipil ipil, (Leucaena } \\
\text { leucocephala), bananas, } \\
\text { kalamansi (Citrus } \\
\text { madurensis) }\end{array}$ & $X$ & & & $X$ & $\mathrm{X}$ & X & & \\
\hline ề & $\begin{array}{l}\text { Sweet potato } \\
\text { Papaya (Carica } \\
\text { papaya), bananas }\end{array}$ & $X$ & & & $\mathrm{X}$ & & $\mathrm{X}$ & & \\
\hline 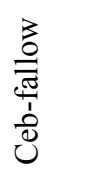 & $\begin{array}{l}\text { Grass } \\
\text { Coconuts } \\
\text { Gmelina, coconuts }\end{array}$ & & & $X$ & & & & $X$ & $\mathrm{X}$ \\
\hline$\frac{\dot{\theta}}{0}$ & $\begin{array}{l}\text { Gmelina } \\
\text { Coconuts }\end{array}$ & & & & & & & X & $\mathrm{X}$ \\
\hline
\end{tabular}


Table 3. (Cont.) Plant species and arrangement within land parcels at Cebuana

\begin{tabular}{|c|c|c|c|c|c|c|c|c|c|c|}
\hline 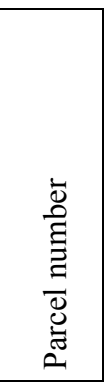 & 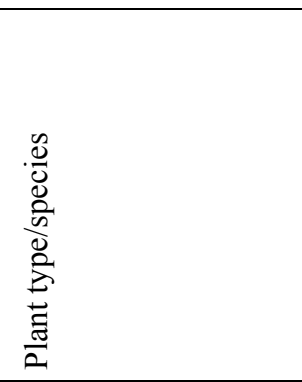 & 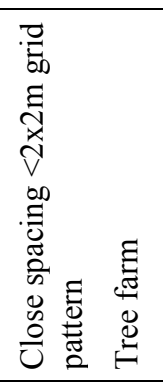 & 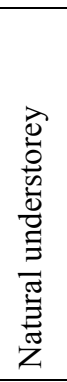 & 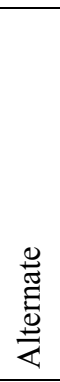 & $\begin{array}{l}\vec{\Xi} \\
\stackrel{\Xi}{0} \\
\dot{D}\end{array}$ & 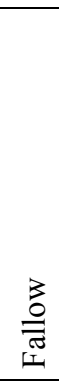 & 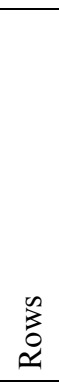 & 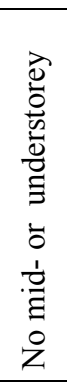 & 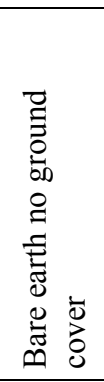 & 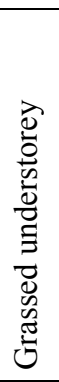 \\
\hline $\begin{array}{l}0 \\
\frac{0}{0} \\
\frac{0}{1} \\
\frac{0}{0}\end{array}$ & $\begin{array}{l}\text { Rice } \\
\text { Mahogany } \\
\text { Gmelina, } \\
\text { mahogany, coconuts } \\
\text { Siqwa (snake gourd) } \\
\text { (Trichosanthes } \\
\text { anquina) }\end{array}$ & & & & $X$ & & & & & \\
\hline 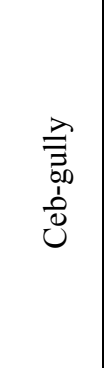 & $\begin{array}{l}\text { Vegetables } \\
\text { Ampalaya } \\
\text { Papaya, Mango } \\
\text { Ipil ipil, (Leucaena } \\
\text { leucocephala), } \\
\text { bananas, kalamansi } \\
\text { (Citrus madurensis) }\end{array}$ & & & $X$ & $X$ & & $\begin{array}{l}X \\
X \\
X\end{array}$ & & & \\
\hline 造全 & $\begin{array}{l}\text { Sweet potato } \\
\text { Papaya (Carica } \\
\text { papaya), bananas }\end{array}$ & & & & $X$ & & & & & \\
\hline $\begin{array}{l}\frac{z}{0} \\
\frac{\bar{\pi}}{4} \\
\frac{1}{0} \\
0\end{array}$ & $\begin{array}{l}\text { Grass } \\
\text { Coconuts } \\
\text { Gmelina, coconuts }\end{array}$ & & & & $X$ & $\mathrm{X}$ & & & & $\begin{array}{l}X \\
X\end{array}$ \\
\hline$\notin$ & $\begin{array}{l}\text { Gmelina } \\
\text { Coconuts }\end{array}$ & & & & & & & $\begin{array}{l}X \\
X\end{array}$ & & $\begin{array}{l}X \\
X\end{array}$ \\
\hline
\end{tabular}


Contribution of Farm Products to Farmers' Livelihood and Household Consumption 101

Table 4. Plant species and their arrangement within land parcels at Mabagon

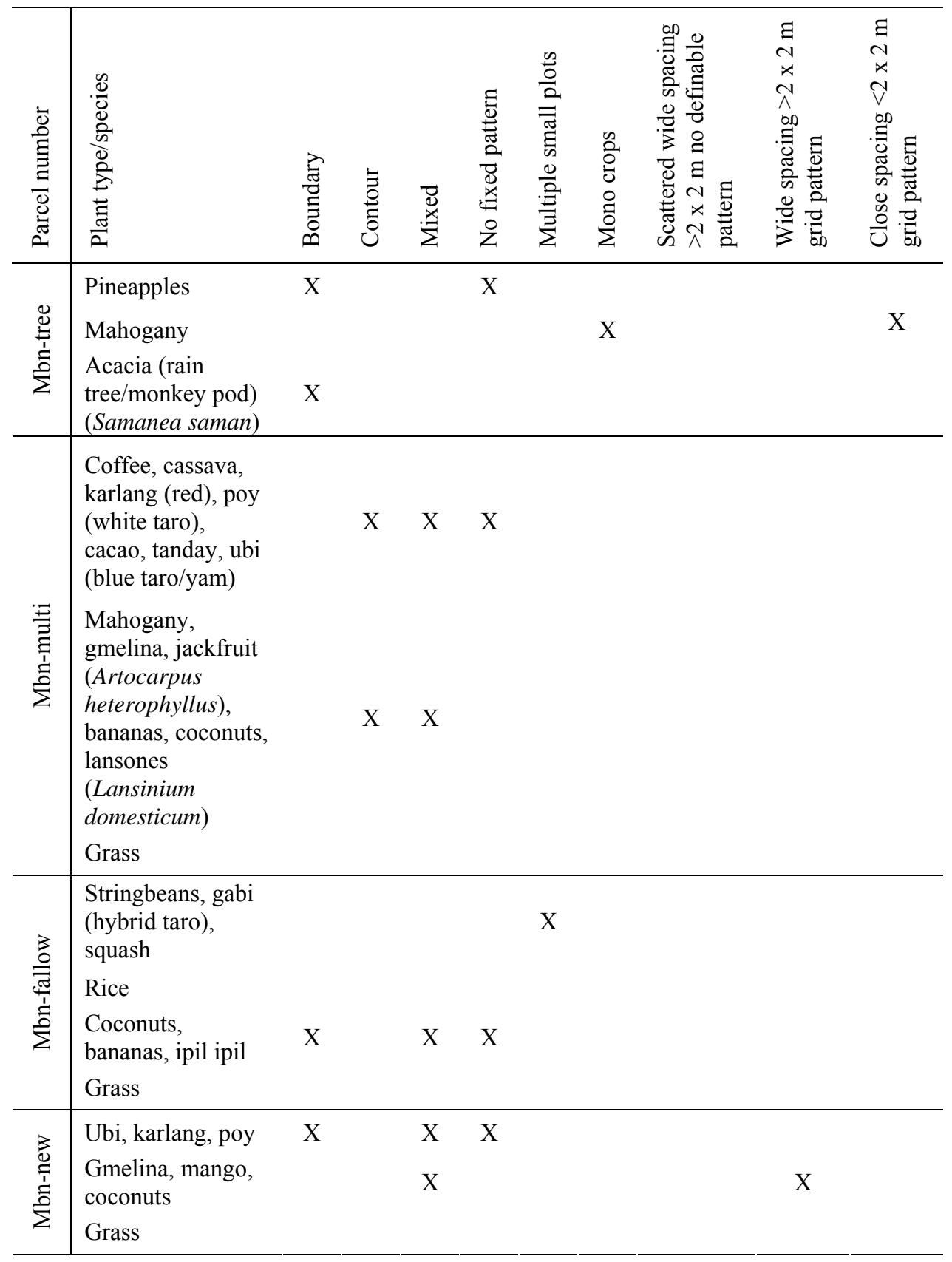


Table 4. (Cont.) Plant species and their arrangement within land parcels at Mabagon

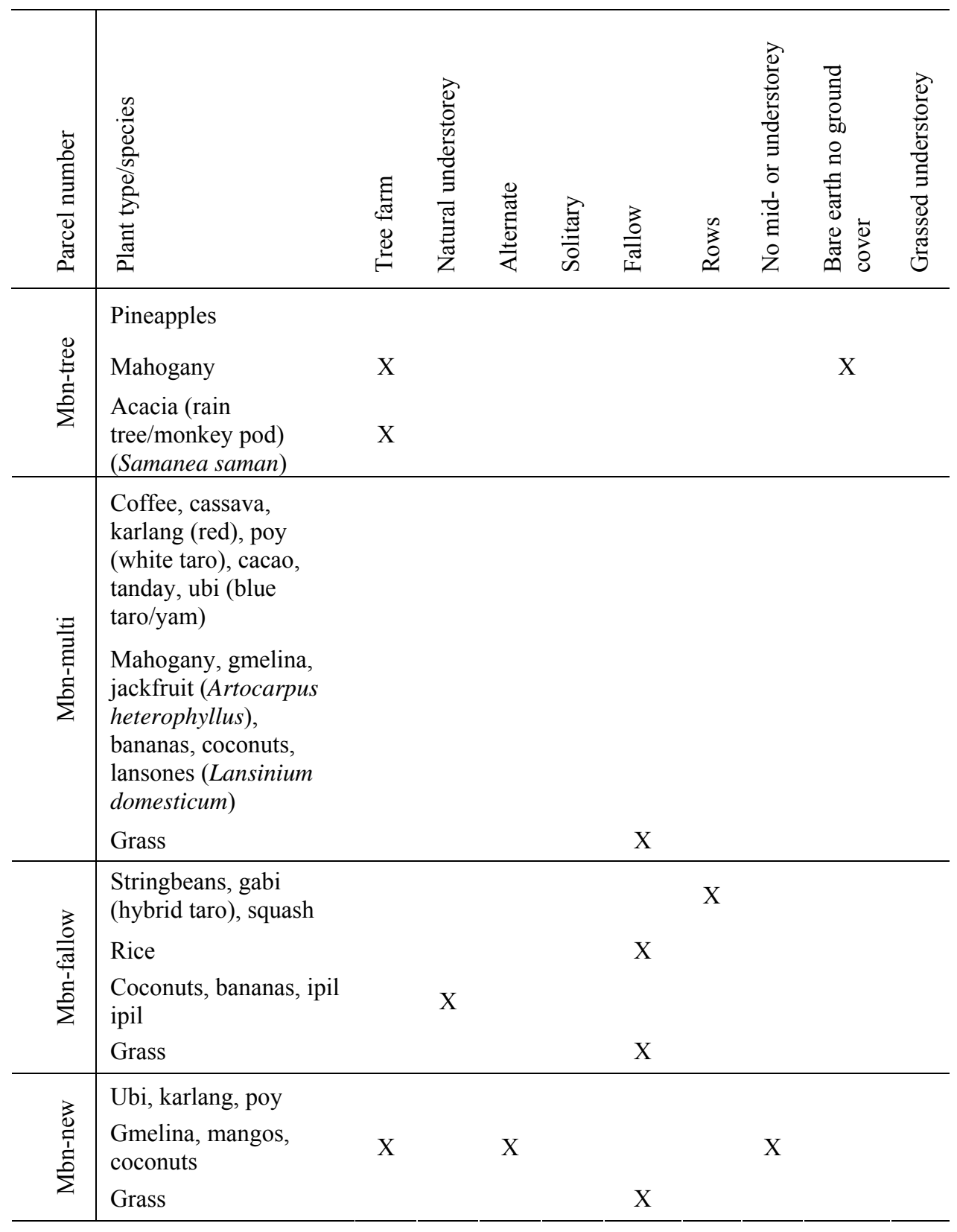




\section{Land Ownership and Tenancy Arrangements}

Most of the land parcels were owned by the farmers, and have been maintained conservatively over many years. The Mbn-multi land parcel was owned by the farmer, his father and brother, but managed by the farmer under tenancy status. The financial arrangement for farm management of Mbn-multi was a coconut income-sharing basis. The Mbn-fallow farm was newly tenanted and the farmer was awaiting a formal agreement regarding future revenue from a rice field that was currently lying fallow. A verbal agreement had been made between the farmer and his relatives (his father and brother) where expenses and gross proceeds from coconut and copra are shared equally between them. The farmer was not obligated to share income from other small crops. Awn-steep land has been owned by the Anahawan farmer for 22 years, and was mostly fallow or naturally regenerated. A portion of Ceb-fallow, owned by the Cebuana farmer for 24 years, has been fallow for five years.

\section{Labour and Other Inputs, and Sources of Income}

The main tasks undertaken to manage the farm parcels include ploughing, fertilizing, weeding and tending rice paddies. The farmers and their families provide most of the labour; however, hired labour was required for maintenance and harvesting of the rice at the Ana-house and Ceb-house land parcels. At the time of this study, the farmer from Mabagon did not employ labour. At the Ceb-house land parcel, cash payment for labour was PhP150/person/wk for 12 hours per week for 1 to 2 labourers to weed and tend rice fields, and 4 to 5 labourers for rice harvesting. Hired labour at Anahawan was paid PhP200/person/week for 5 to 15 hours per week. Sacks of the harvested unprocessed rice were given to the labourers at Anahawan either in lieu of or in conjunction with cash payment. No hired labour was used to maintain trees or the other crop categories across the three farms.

Insecticide and fertilizer were widely used on rice, coconuts and other crops at Anahawan and on main crops at the Cebuana farms. A subsidy on fertilizer was provided to each of the three farmers by the Philippines Coconut Authority (PCA). The farmers planted other crops downslope of the fertilized trees to take advantage of leached nutrients. With the exception of treatment costs required for pigs, little or no expenditure was made on animal health. The carabao and pig were tethered and relocated daily at different sites on-farm and at neighbouring farms, while the chickens on the three farms were free ranging.

In addition to farm-derived income, the male farm owners from the Cebuana and Mabagon farms earned additional income from carpentry, and the Anahawan farm owner supplemented his income by driving a hubal-hubal (a multi-passenger motorcycle). The Cebuana farmer also value-added his income by making furniture from timber harvested from his farm. The carpenter at Mabagon also did decorative woodcarving. 


\section{Farm Product Types and Quantities Used by Households}

The farmers listed food and other farm-grown products that they consumed during the four-week survey period. These are categorised as:

- Main crops (MC) grown as the main source of farm-derived income from industrial processing and marketing activities. Main crops generally consist of coconuts, which are sold to the PCA (the national agricultural body that regulates the marketing and export of coconut products and by-products), rice (which is sold to and distributed by regional rice processors), and trees (which are grown for lumber and other timber and non-timber products).

- Other crops (OC) grown for sale at local markets. Crops including eggplant, sweet potato and bitter melon are grown specifically for sale. Produce is harvested and delivered twice per week to the local markets.

- Isolated or grouped (IG) products grown on farmland mostly for home use. These include fruit trees planted as boundary markers or with no fixed pattern and various vegetable species.

- Crops grown near the house $(\mathrm{H})$, specifically for home consumption.

- Other non-edible products (OP), including woody stems, leaves and debris collected from under trees as firewood for cooking and repelling mosquitoes.

Many of the plants grown on the farms are introduced species. Coconuts, okra, talong (eggplant) and bago (rainforest tree) (Gnetum gnemon) are believed to be native to the Philippines. Leaves of the Filipino indigenous bago tree are consumed as a vegetable. Gmelina and mahogany ${ }^{1}$ are principally grown for income generation (lumber and fuelwood), investment and children's inheritance.

The frequency with which food and other products were consumed by the three farms was assessed across each of the categories. The largest variety of food types for on-farm consumption was found at the Anahawan farm. The highest proportion of isolated or grouped (IG) non-marketable crops was consumed at the Cebuana farm, and the highest number of other crops (OC) at the Mabagon farm. No food products were consumed from the house at Cebuana. The main crops (MC) category was the least consumed at Anahawan and Cebuana. The Mabagon household consumed no main crops.

All three households consumed taglong (eggplant). The Anahawan household consumed the largest proportion of eggplant, papaya and ganas (sweet potato tops). Neighbouring households Anahawan and Cebuana consumed camote (sweet potato), kalamansi (lemonsito, a species of lime fruit) and lube (coconut). The Cebuana and Mabagon households consumed ampalaya (bitter melon), bananas and okra. Foods with the highest frequency of consumption by each household during the four weeks included taglong, camote, atsal (pepper, Capsicum annum), kalamanci, coconuts,

\footnotetext{
${ }^{1}$ Gmelina and mahogany are introduced tree species.
} 
ampalaya and kangkong (water spinach, a green leafy vegetable). There were numerous food types that were consumed only once by separate households during the four-week period. The family at Anahawan consumed six vegetable and six fruit types whereas the family at Cebuana consumed more fruits than vegetables, and the family at Mabagon mostly consumed vegetables.

\section{Awareness of the Nutritional Value and Health Benefits of Plants Consumed On- farm}

Farmers nominated food groups consumed by the household and ranked the value of nutritional importance on a scale of one to five, one being the lowest and five the highest. With the exception of vegetables being excluded by the Mabagon farmer, rankings across all farms were maintained at three and above indicating moderate to high importance in the diet for nutritional benefits of these products (Table 5).

Table 5. Ranking in order of importance of nutrition in household health requirements

\begin{tabular}{lccc}
\hline \multirow{2}{*}{ Product } & \multicolumn{3}{c}{ Household } \\
\cline { 2 - 4 } & Anahawan & Cebuana & Mabagon \\
\hline Rice & 5 & - & - \\
Vegetables & 5 & 4 & - \\
Fruit & 5 & 3 & - \\
Meat & 4 & 4 & 5 \\
Eggs & 4 & 3 & 5 \\
Sweet potatoes & 3 & - & - \\
Bananas & - & - & 4 \\
\hline
\end{tabular}

Ranking: $1=$ least important, to $5=$ most important. A dash indicates the farmer did not rank the product.

The farmers were also aware of health benefits of products that they consumed or used for specific ailments. These products include opyo rainforest tree (golden shower/cassia) (Cassia fistula), which was retained at Anahawan specifically for stomach ache and as a laxative. The farmers consumed camote, and ganas, kangkong and poy as a source of energy. Young ampalaya leaves, vine shoots and fruit were considered useful in the treatment of Type 2 Diabetes mellitus. Camote and ganas are also known as blood sugar regulators for sufferers of diabetes.

\section{Benefits and Savings of On-farm Products Used for Home Consumption}

Prices of products used on-farm were elicited on the basis of market prices net of production cost. Cost savings were estimated as the monetary difference between farmgate prices, and transportation costs and market retail prices. 
The food types that were used for home consumption from the main crops category were rice and coconuts. The farmer at Anahawan estimated a cost saving of $\mathrm{PhP} 287.50 / \mathrm{wk}$ for rice. Coconut milk is used as a substitute for water for the farmer working in the fields at Anahawan. The farmer estimated that the net value of the coconuts that were consumed in the field would have been $\mathrm{PhP} 8$ per fruit. Coconuts harvested as required by the household at Anahawan generated an overall weekly cost saving of PhP200.

A cost saving of PhP70/wk was generated by the Anahawan household for nonfood products through use of fuelwood and leaf litter gathered from gmelina and acacia trees. Gmelina, which usually costs PhP14/board foot clean, was also used as lumber by the Cebuana household. Mahogany poles and boards were used at Cebuana for house construction. No overall saving was estimated because the farmer was unable to estimate the volume of timber used during construction over the four weeks. Ipil ipil used for fuel at the Mabagon farm saved PhP125/wk.

Fresh products were exchanged between neighbouring farmers and relatives, and bamboo was made available free of charge to local community members for construction if the purpose was for personal use. Coconut shells and husks were left at the land parcels where the product was harvested, i.e. there was no cost to the community for coconut shells for making charcoal if this was for home consumption. However, if these bamboo or coconut products were to be subsequently sold then a charge was imposed.

Carabao and pigs were tethered for grazing, and relocated daily, which involved a labour input. The farmers did not record labour times. No carabao were slaughtered during the four-week record keeping period. Poultry (chickens) were kept at the three households for meat and eggs, and had free range around the farmers' houses. Pigs and chickens were fed on household and coconut scraps. Compared to the current market price, the farmers generated weekly savings of PhP24 for eggs and PhP25 for poultry meat at the Anahawan farm, and $\mathrm{PhP} 90$ for eggs and $\mathrm{PhP} 150$ for poultry meat at the Cebuana farm.

\section{DISCUSSION}

Heterogeneity of crop-tree arrangements within and between farms indicated that management decisions were made on a parcel-by-parcel basis. Each parcel is a dynamic system and plantings occur where they are best suited at any given time. With the exception of a few parcels that could be defined as boundary plantings with trees and shrubs, mono-crops or multiple level contour plantings, the balance of the parcels consisted of a mixture of small plots of crops among scattered or isolated trees. Gmelina and mahogany, which are used for lumber, fuel and construction materials act as boundary indicators around vegetable block plantings. The vegetables are grown in single-species blocks specifically to sell at the local markets. There was evidence of crop rotations and fallow plots. There was a tendency for the farmers to intercrop with 
coconuts. The farmers reported that the trees and crops simultaneously received the nutrient benefits of fertilizer application. This practice was observed at Mbn-multi, where young mahogany trees benefited from crop fertilizer inputs and weeding. The Anahawan farmer also planted crops downslope from coconuts, so as to indirectly receive the PCA subsidised fertilizer, and hence considered it a saving.

Labour and other input costs appear to be linked to the product type. Rice required more intensive labour than coconut or trees. The farmers at Cebuana and Mabagon had carpentry skills with the ability to add value to their own timber. At the time of this study, these farmers appeared to focus more on trees than crops for home consumption. All farms benefited from the PCA fertilizer subsidy.

The proportion of fruit and vegetables consumed on the three farms reflected the crop types produced on each of the farms. For example, in-season vegetables were abundant in the home garden at Anahawan, where the highest proportion of farmgrown produce was consumed, whereas only a small quantity of vegetables was grown on the Cebuana farm, the household with the lowest consumption of farm-grown produce.

Livestock and poultry were kept at all three households and constituted an important component of the integrated farm-household system. Pigs and chickens were fed with household food scraps and coconut leftovers and were allowed to seek food in the area surrounding the house.

Although the farmers did not mention the nutritional properties of each of the food groups they consumed, they were aware of several medicinal and nutritional benefits. The farmers retained particular native plant species, and made use of other crops specifically for medicinal use. This indicated that they had a basic understanding of the value of the products to their daily nutrition and health requirements.

The farmers from the three farms believed that they saved money by consuming farm-grown products. They also stated that they were assured of fresh chemical-free food, because they refrained from harvesting within the recommended term within which residual chemicals would be present on the crops. Food sharing (bartering) took place in the communities, presenting the case study households with increased variety in their diets. The farmers also provided community benefit through sharing products that were left in situ to be converted into fuel and other useable non-commercial products.

\section{CONCLUSION}

This study provided a descriptive overview of the farming systems of the three case study farms and how farm products contributed to consumption and livelihood within a short timeframe. There is no single definitive description of the three case study farming systems. They are dynamic systems determined by complex biophysical, economic and social interactions between the people and their environment. More quantitative studies of farming systems and how farmer's 
livelihoods are sustained in the longer term, would ensure that crop rotations and harvesting variables on the same parcel of land are represented.

\section{REFERENCES}

DENAMANY, G.M., AHMAD, M.S., bin, and N. HAMID, bin. 1979. Coconut intercropping systems in Peninsular Malaysia. Oleagineux. 34(1): 7-15.

DEVENDRA, C. and D. THOMAS. 2002. Smallholder farming systems in Asia. Agricultural Systems. 71(1): 17-25.

FREI, M. and K. BECKER. 2004. Agro-biodiversity in subsistence-oriented farming systems in a Philippine upland region: nutritional considerations. Biodiversity and Conservation. 13(8): $1591-1610$

GOMEZ, A.A. and K.A. GOMEZ. 1983. Multiple Cropping in the Humid Tropics of Asia. LDRC, Ottawa, Canada.

ICRAF, n.d., A Tree Species and Reference Guide. World Agroforestry Centre, Plant Resources of South-East Asia Network, http://www.worldagroforestrycentre.org/sea/Products/AFDbases/ AF/asp/SpeciesInfo.asp?SpID=914. Accessed 12 January 2007.

LEWIS, W.H. 1977. Medical Botany Plants Affecting Man's Health. Wiley, New York.

LGU (LOCAL GOVERNMENT UNIT) Hindang. 2000. Comprehensive Land Use Plan (CLUP) for the Municipality of Hindang, Leyte, the Philippines. Local Government Unit, Hindang, Leyte.

MAGCALE-MACANDOG, D.B. Visco, R.G. and M.E.M. Delgado. 2006. Agroforestry adoption, innovations and smallholder farmers' motivations in tropical uplands of southern Philippines. Journal of Sustainable Agriculture. 28(1): 131-143.

NISSEN, T.M., MIDMORE, D.J. and A.G. KEELER. 2001. Biophysical and economic tradeoffs of intercropping timber with food crops in the Philippine uplands. Agricultural Systems. 67(1): 49-69.

SMITHSON, P. ADDISON, K. and K. ATKINSON. 2002. Fundamentals of the Physical Environment. 3rd edn. Routledge, London, pp. 266-7.

UPTON, M. 1996. The Economics of Tropical Farming Systems. Cambridge University Press, Cambridge. 